\title{
THE EVANGELICAL CHRISTIANS-BAPTISTS: BETWEEN THE RELIGIOUS TRADITION OF RUSSIA AND FOREIGN INFLUENCE
}

\begin{abstract}
Grzegorz Pełczyński, The Evangelical Christians-Baptists: between the religious tradition of Russia and foreign influence, edited by Z. Drozdowicz and S. Sztajer, "Człowiek i Społeczeństwo" vol. XLI, Poznań 2016, pp. 71-89, Adam Mickiewicz University Press. ISSN 0239-3271.

Evangelical Christians and Baptists are Evangelical denominations representing Protestant beliefs in Russia. They share a similar approach to doctrinal matters and at one point in history united into a single ecclesiastical organisation. Domestic factors, in particular, as well as foreign influences played an important role in the Russian origins of Evangelical groups, which contributed to the Evangelical movement's religious inquisitiveness, spiritual fervour, and readiness for martyrdom around the world. In order to develop a thorough understanding of Evangelical Christians and Baptists in Russia, one needs to explore their political and cultural backgrounds.
\end{abstract}

Grzegorz Pełczyński, University of Wroclaw, Faculty of Humanities, Chair of Ethnology and Cultural Anthropology, ul. Szewska 50/51, 50-139 Wrocław, Poland, e-mail: grzegorz.pelczynski@uwr.edu.pl

In light of the religious pluralism found in Russia, attempting to come up with any authoritative answer on the religious specificity of the country must appear as a daunting challenge. ${ }^{1}$ The difficulty, however, lies not so much in grasping the diversity of religious life in Russia, but rather in recognizing how those religious varieties relate to each other. And it must be said that

${ }^{1}$ P. Stawiński, Sekty schizmy i herezje w Rosji (słownik), Musica lagellonica, Kraków 2000; R. Pipes, Rosja carów, transl. W. Jeżewski, Magnum, Warszawa 2006, pp. 227-253; G. Pełczyński, Religia w dziejach cywilizacji rosyjskiej, in M. Łoboz, A. Brzyski OFM (eds), Zawstydzona mq̨drość. Prace ofiarowane Ojcu Profesorowi Franciszkowi Rosińskiemu OFM, Franciszkańskie Wydawnictwo Św. Antoniego, Wrocław 2013, pp. 247-260. 
their "mutual relationships" are often antagonistic, and one is expected to take sides.

The following remarks are offered by an individual native to Poland, which has never been so religiously diverse as Russia: A Pole may be somewhat baffled by the seriousness with which Russians tend to approach religious matters, and it may also come across as paradoxical to think about Russian irreligiousness, or downright atheism, that makes western religious indifference pale in comparison. Clearly, religious life in Russia is something entirely different than what a Pole could even begin to imagine.

For a casual observer Russia is an orthodox country. This comes as no surprise if one considers the purely visual appeal of the Orthodox Church. Indeed, its significance for Russia cannot be underestimated, and over the course of history the Orthodox Church forged close and lasting ties with the secular power. These culminated in the $18^{\text {th }}$ century when the Orthodox Church was instituted as a state religion governed by the Holy Synod, and from then on it often served to promote the political ends of the Romanov Empire. Thus, anything that opposed the Orthodox Church was also perceived as a challenge to the authority of the state, and inevitably provoked a retaliation of the powers that be. ${ }^{2}$

But the believers in Russia include not only those faithful to the Russian Orthodox Church. In the middle of the $16^{\text {th }}$ century, there occurred in Russia a religious rupture called Raskol: regardless of their social background, thousands of Russians rebelled against the liturgical reform pursued by the patriarch Nikon, and seceded from the official church to practice the old rituals in remote parts of the land. These Old Believers, or Old Ritual Believers, quickly broke into various sects, with the Christian nature of some of them being rather questionable. But there were also some Russians strongly attracted to western Christianity. Catholicism was never particularly popular with Russians, although some varieties of Protestantism did take root in the empire. Let us also briefly note other religions such as Judaism, Islam, Buddhism, and, finally, indigenous religions of the peoples of the north. It was rarely Russians, or those considering themselves to be Russians, who subscribed to these religions, but they nevertheless had their share in shaping the religious landscape of Russia. And let us not forget that for some time it has been shaped by atheism, clearly sometimes a form of belief as strong as religion itself.

${ }^{2}$ M. Heller, Historia imperium rosyjskiego, transl. E. Melech, T. Kaczmarek, Książka i Wiedza, Warszawa 2009, pp. 346-347. 
One of such non-orthodox religious groups in Russia as mentioned above is Evangelical Christian-Baptists. Its relatively recent emergence would suggest that this undeniably Protestant denomination, however not without foreign inspirations, is first and foremost of Russian making. It therefore stands on its own as a Protestant faith, and this concerns particularly Evangelical beliefs. Thus, putting conscious conversion front and centre as an essential part of the Christian experience, the Evangelical Christians-Baptists may be compared with other similar denominations that include Methodists, Baptists, or Pentecostals. ${ }^{3}$

Most of the dissenting religious movements in Russia have their origins in Raskol. Emerging in the wake of this great schism, it was particularly Molokans who most inspired the rise of Evangelical Christians and Baptists. Having broken away from an earlier sect of Doukhobors, Molokans are said to be have been founded by Semen Uklein, a spiritual leader active in the second half of the $18^{\text {th }}$ century, and initially a Doukhobor himself. Uklein firmly believed the Scripture to be the primary source of faith, while Doukhobors insisted on the idea of personal experience of God.

Various efforts pursued by Uklein and his followers helped spread Molokan beliefs across Russia, reaching also to such remote parts of the empire as Siberia and the Caucasus. Secluded from one another, these various Molokan communities developed diverse religious rites. For example, Don Molokans, headed by Andrey Salamatin in the Taurida Governorate, largely followed the Orthodox line of teaching, but also had close ties to Protestantism. Protestant ideas were undeniably most akin to the beliefs of the Water Molokans who emerged in Transcaucasia at the turn of the 1840s and 1850s, when their study of the Gospel led them to a conclusion that it is essential to perform baptism (of adults) and bread-breaking. ${ }^{4}$

The origins of Evangelical Christian-Baptists in Russia go back also to the Mennonites, who were founded by Menno Simons and emerged from the Anabaptist movement during the Reformation in Germany and the Netherlands. ${ }^{5}$ The baptism of adults practiced by the Mennonites, as well as their pacifism that made them conscientiously object to military service, led to their persecution and ostracism in western Europe. Down on their fortunes,

3 T.J. Zieliński, Protestantyzm ewangelikalny, Credo, Katowice 2014, pp. 121-170.

${ }^{4}$ A. Klibanow, Istorija religioznogo sektanstwa w Rossiii, Nauka, Moskwa 1965, pp. 122-165; S. Sawinskij, Istorija ewangel'skich christian-baptistow Ukrainy, Rossii, Belorussii (1867-1917), Biblija dlja wsech, Sankt Peterburg 1999, pp. 48-52.

${ }^{5}$ W.R. Estep, Anababtyści, tłum. K. Wiazowski, Wyższe Baptystyczne Seminarium Teologiczne, Warszawa 2009, pp. 165-180. 
some left for Russia to settle on the recently won lands along the coast of the Black Sea where, over the following decades, they formed vibrant and thriving farming communities ${ }^{6}$ into which they would also welcome Lutherans who had decided on leaving Germany. Although both these persuasions were Protestant, they were looked kindly upon by the powers that be, which allowed foreigners to exercise their religion as long as they were not trying to proselytise Orthodox believers.

But over time, the religious beliefs of the Mennonites and Lutherans populating the southern lands of the European part of Russia lost their lively spirit, prompting some to seek remedies that would revive their fading faith. This renewal came in 1845 with Edward Wüst, a Lutheran preacher from Germany and a devoted supporter of Pietism, a movement seeking to restore the emotionality of faith. ${ }^{7}$ He did bring a religious awakening, particularly among the Mennonites, ${ }^{8}$ but also caused deep rifts among the believers, some of whom eventually remained committed to their traditional beliefs and practices, while others, like the Mennonite Brethren, embraced an increasingly zealous spirit.

Baptism and Evangelical Christianity could spread in the Russian Empire also thanks to the growing readership of the Scripture. The Russian Bible Society was founded in 1813, not without inspiration from the British and Foreign Bible Society, and its most ambitious undertaking included a modern translation of the New Testament. Unfortunately, the Russian Bible Society was closed down in 1826 following the intervention of influential conservative circles, which argued that popular study of the Bible may lead to upheaval and disrupt social order. ${ }^{9}$ It was, therefore, not before the 1860 s, during the liberal reign of Alexander II, that the Scripture became widely available to the Russian public once again. ${ }^{10}$ The efforts of the enthusiasts of the Scripture culminated in 1876 with the publication of the Synodal Bible, its name derived from the Most Holy Synod that sponsored its release.

${ }^{6}$ H.S. Bender, Menonici i ich dziedzictwo, tłum. J. Wierszyłowski, Peniel Amish Mennonite Church, b.m.r.w., pp. 73-79; C.J. Dyck, An Introduction to Mennonite History. A Popular History of the Anababtist and the Mennonites, Herald Press, Scottdale 1993, pp. 168-170.

7 J. Billington, Ikona i topór. Historia kultury rosyjskiej, transl. J. Hunia, Wyd. Uniwersytetu Jagiellońskiego, Kraków 2008, pp. 256-257.

${ }^{8}$ A. Karew, Russkoe ewangel'sko-baptitskoe dwiżenie, "Almanach po istorii russkogo baptizma” 2006, p. 87; S. Sawinskij, Istorija..., pp. 71-74.

${ }_{9}^{9}$ I. Czistowicz, Istorija perewoda Biblii na russkij jazyk, Rossijskoe Biblijskoe Obszczestvo, Moskwa 1997, pp. 16-17.

${ }^{10}$ M. Riżskij, Russkaja biblija. Istorija perewodow biblii w Rossii, Awalon, Sankt Peterburg 2007, pp. 200-219. 
All of these groups: Molokans, particularly Water Molokans, Mennonites, and those seeking to make the Bible widely available to the Russian reader, set the stage for the massive religious awakening that came in Russia in the middle of the $19^{\text {th }}$ century. It was at first a religious movement, ${ }^{11}$ a term sociologists use to describe social phenomena that operate without much of a formal structure. But it brought together thousands of people disheartened by the state Church, inspiring them to live by values as they saw them preached in the Gospel. But if the movement did bring to life some organizations or institutions, these were rather stand-alone initiatives addressing particular matters without any overarching purpose. Instilling the ideas of Evangelical Christianity into the Russia of the day would best succeed as a movement.

Historians believe that this movement was born nearly simultaneously in southern Russia, the Caucasus, Crimea, and Saint Petersburg. ${ }^{12}$ Let us first discuss the developments of the Mennonite and Lutheran communities. As already noted, inspired by German preachers such as Wüst, the awakening here had already been well underway since the first half of the century. During this time, the colony of Rorbach served as an important community radiating the spirit of this religious awakening, manifesting itself, among others, in Bible hours, which were also eagerly frequented by Russian peasants. ${ }^{13}$

In 1861, Alexander II emancipated the Russian serfs who were now able to move freely around the empire. Some of them headed down to the southern lands of the European part of Russia where they would find work with the religiously awakened Mennonites, who were keen to welcome these Russian servants during their Bible hours. Some of these Russian serfs staying at the time in the colonies of Rorbach, Libenau, or Novyi Dantsig, were inspired by these meetings, filled with prayer and scriptural meditations. What they heard and experienced transformed them entirely, and they were returning to their home lands as ardent believers, passionate to preach their new faith to others, and soon started organising Bible hours to spread the faith among their fellow countrymen. They came to be known as Stundists (from the

${ }^{11}$ Por. T.J. Zieliński, Protestantyzm ewangelikalny, p. 257.

12 This belief was largely spread already at the turn of the $20^{\text {th }}$ century: W. Pawłow, Prawda o baptistach. Oczerk istorii cerkownoga ustrojstwa i principow baptistskich obszczin, "Baptist” 43-47/1911, reprint: “Almanach po istorii russkogo baptizma” 2006, pp. 220-272.

${ }^{13}$ A. Karew, Russkoe..., p. 91. 
German Bibelstunde: Bibel - Bible, Stunde - hour), and the movement as a whole was called Stundism. ${ }^{14}$

Stundism quickly began developing ties with Baptism, most often brought about by the Mennonites ${ }^{15}$ who were the first to practice adult baptism, although it must be noted that Baptists treat baptism not only as a fully conscious act of an individual, but also as a rite that testifies that one has become a believer, atoned for one's sins, and embraced the new faith. Also, Mennonites performed baptism by pouring water, while Baptists do so by immersion. By this time, Baptism, until recently rather an Anglo-saxon phenomenon, ${ }^{16}$ had been growing rapidly on the continent, not least thanks to the efforts pursued by Johann Oncken and his mission in Hamburg. The spiritually awakened Mennonites from southern Russia reached out to the mission, and in 1869 Oncken travelled to Russia where he preached and baptised in the colonies of Einlage, as well as Staryi and Novyi Dantsig. This said, most of the Baptist churches were founded by missionaries coming from the Mennonite community: Gerhard and Johannes Willer, Abraham Unger, Johann Pritzkau, and others. These new churches were increasingly attracting also Russians and Ukrainians, who contributed to the cause such notable missionaries as Efim Tsymbal or Ivan Riaboshapka, who took to preaching among Slavic populations.

The new movement also had its followers in Transcaucasia, which was already populated by Molokans, in particular Water Molokans, who had close ties to Protestant creeds. A prominent figure that helped spread the new faith was Martin Kalweit, a German who had embraced the Baptist faith in 1858, while in Lithuania, and who moved to settle in Tiflis five years later. Kalweit at one point made acquaintance with Nikita Voronin, a young Molokan showing great interest in Baptist teachings. They soon started engaging in discussions which brought Voronin to the conclusion that it is essential to perform baptism through immersion. Kalweit eventually baptised Voronin in Tiflis on the bank of the river Kur on 13 August 1867, thus marking the beginning of Baptism in Russia. ${ }^{17}$ To be sure, it was not the first baptism in Russia performed in this manner as some Germans who had settled in the Russian Empire had been practicing it already for some time, for example

${ }^{14}$ S. Golowaszczenko (ed.), Istorija ewangel'sko-baptistskogo dwiżenija w Ukrainie. Materiały i dokumenty, Odessa 1998, p. 9-71; A. Karew, Russkoe..., p. 88-89; S. Sawinskij, Istorija..., pp. 95-104.

${ }^{15}$ H.L. McBeth, The Baptist Heritage, Broadman Press, Nashville 1987, p. 465.

16 T.J. Zieliński, Ewangelikalny protestantyzm..., pp. 51-64.

${ }^{17}$ A. Byczkow, 110-letie russko-ukrainskogo bratstwa ECHB, "Bratskij Westnik" 5/1977, p. 67; H.L. McBeth, The Baptist Heritage..., p. 490. 
in Poland where Gustav Alf was baptised in this way in $1858 .{ }^{18}$ Voronin, however, was Russian, and, quite surprisingly, it was in Georgia, where Russian Baptism first made its mark.

Let us now discuss how the movement was spreading in Taurida Governorate in Crimea. As already noted, it was home to the sect of Don Molokans, the followers of Andrey Salamatin. In 1866 the sect was joined by Yakov Delyakovitsch Delyakov, an Assyrian settled in Russia. Himself a Presbyterian, Dylyakov was largely sympathetic to the sect, which administered sacraments (except for ordination and anointment of the sick), and practiced infant baptism, which was also very much a Presbyterian tradition. Delyakov preached to them the Lord's love in Jesus Christ and justification by faith. ${ }^{19}$

Among Delyakov's followers were two brothers, Khariton and Zinovii Zakharov, who became essential figures in the eventual revival of the Crimean community of the Molokans. These New Molokans, or Evangelical Christians-Zakharovs, as they came to be known, largely shared their religious ideas with the Baptists, although the former performed baptism not only on adults, but also on infants, and practiced foot washing, a custom possibly adopted from the Mennonites living nearby. ${ }^{20}$

By the late 1870s Baptist preachers were spreading their teachings among the followers of Zakharov. New Molokans had been reluctant at first, but many of them gradually were won over to the idea of baptism on the basis of faith, eventually giving rise to Baptist churches.

In Saint Petersburg, the Evangelical movement had a curious dynamic of its own. It first began in 1874 with the noblewoman Elizaveta Chertko$\mathrm{va}^{21}$ arranging for Lord Granville Redstock, ${ }^{22}$ an Evangelical preacher from England whom she met in Switzerland, to come to Russia.

Redstock presided over his meetings in the salons of Saint Petersburg, preaching that the necessary path to salvation leads through believing, conversion, and sanctification. Noble women had nothing against common people absorbing the message of the "Lord apostle," and soon various social classes mingled at the religious meetings arranged in aristocratic settings. ${ }^{23}$

${ }^{18}$ A.W. Wardin, Gotfryd Fryderyk Alf. Pionier ruchu baptystycznego na ziemiach polskich, tłum. K. Wiazowski, Wyższe Baptystyczne Serminarium Teologiczne, Warszawa 2003, p. 28.

${ }^{19}$ E. Filimonowa, Żiwaja wera pokolenij, Protestant, Moskwa 2009, pp. 14-15.

20 S. Sawinskij, Istorija..., pp. 157-158.

${ }^{21}$ M. Karetnikowa, Istorija petersburskoj cerkvi evangel'skich christian-baptistov, “Almanach po istorii russkogo baptizma” 2/2001, pp. 21-23.

${ }^{22}$ E. Hejer, Religioznyj raskol w srede rossijskich aristokratow w 1860-1900 gody. Redstokizm i paszkowszczina, Moskwa 2002, pp. 41-42.

${ }^{23}$ Ibidem, p. 55. 
Ms Chertkova's guest stayed in Saint Petersburg for several months, later returning to Russia on two more occasions, in 1875 and 1878, in any case leaving behind large numbers of believers. Inspired by his teachings, some of his followers severed their ties with the Orthodox Church, while others embraced the state religion more fully than before. Those converted by Redstock included members of the nobility, for example Princess Natalia Liven, Count Modest Korf, Count Alexei Bobrinskii, minister of transportation, or Vasilii Pashkov, one of the wealthiest people in Russia. ${ }^{24}$ These figures all came to play prominent roles in the growth of Evangelicalism in Russia.

Gaining momentum in southern Russia, Ukraine, Transcaucasia, Crimea and Saint Petersburg, these movements were anything but local affairs. Those who were converted, particularly if eventually baptised, often took to missionary work, spreading their beliefs to lands where they were not previously known. The movement was also growing thanks to some advantageous circumstances, including an increasing disappointment with the Orthodox Church, the freedom to move around the empire, and the financial backing of wealthy supporters.

The state authorities were looking at all this with great concern. They tended to tolerate German Protestants, Lutherans or Baptists, and were accustomed to dealing with various sects, but the Evangelical movement was becoming a force to be reckoned with. To counter it, various legislative measures were adopted to contain, or even extinguish, the movement, and its followers would endure much persecution before religious freedom for the non-Orthodox denominations was secured in 1905 with the adoption of the Edict of Toleration. This may not always have been respected, but undeniably helped Evangelicalism grow in Russia. ${ }^{25}$

Over the years the movement started resembling a Church proper following various efforts to form it into a single whole. To this end, between 1 and 5 April 1884 a congress was called in Saint Petersburg for the representatives of various religious groups including Evangelical Christians, Baptists, Mennonite Brethren, Stundists, and the followers of Zakharov. It is unfortunately difficult to say whether a united organisation would eventually emerge following this initiative as the police apprehended and expelled all the delegates to their respective places of residence. ${ }^{26} \mathrm{~A}$ couple of weeks later, between 30 April and 1 May, in Novovasilevka in Taurida Governo-

${ }^{24}$ S. Liven, Duchownoe probużdenie w Rossii, "Bratskij Westnik” 5-6/1996, pp. 31-36.

${ }^{25}$ For referenced legislation see S. Golowaszczenko (ed.), Istorija evangel'sko baptistkogo dviżenija..., pp. 190-224.

${ }^{26}$ M. Karetnikowa, Istorija petersburskoj..., pp. 39-45. 
rate, delegates from Southern Russia, Ukraine and the Caucasus, founded the Russian Baptist Union, appointing Ivan Willer from the Mennonite Brethren as its chair. ${ }^{27}$ It took much longer to put into place ecclesiastical structures in northern Russia. It may have been because Modest Korf and Vasilii Pashkov, the likely leaders of the community in northern Russia and also organizers of the congress in Saint Petersburg in 1884, were banished from Russia, or perhaps because the followers of Pashkov did not see much reason in building these structures. At the beginning of the $20^{\text {th }}$ century, a religious firebrand, Ivan Prokhanov, born into a Molokan family, took advantage of the broader religious freedom and founded the All-Russian Union of Evangelical Christians, in 1909. ${ }^{28}$

The Evangelical movement did not eventually become integrated into a single organisation, but it does not mean that it suffered from divisions. The organisations shared similar goals, worked together, and eventually joined the Baptist World Alliance, where Prokhanov served as vice-president from 1911. This said, the Evangelical Christians from the north were more liberal and open to working with anyone willing to evangelize Russia, whereas the Baptists from the South were more focused on establishing secure and well functioning ecclesiastical structures.

When the October Revolution first broke out, both of these communities were already occupying a significant position in the religious landscape of Russia, but at the beginning the Bolsheviks showed little concern for Evangelicals and Baptists, perceiving the Orthodox Church to be the primary religious force to be dispensed with. On 23 January 1918, the Council of the People's Commissars issued a Decree on the Separation of the Church from the State and the Schools from the Church. Under the decree, all religions were given equal rights, while the Orthodox Church was stripped of any privileges it had previously enjoyed. But it also provided that one's religious beliefs could not stand in the way of carrying out citizen's duties. Also, religious communities could no longer have legal personhood, which meant, among other things, that they were not allowed to own property. ${ }^{29}$ Hoping for tolerance and broader freedom to exercise their beliefs, Evangelical Christians and Baptists generally welcomed the decree, even if they were not particularly enthusiastic about the restrictions imposed on property rights.

27 S. Sawinskij, Istorija..., pp. 200-202.

${ }^{28}$ W. Popow, Prochanow - organizator ewangel'skogo dwiżenija, "Bratskij Westnik" 5/1989, pp. 57-58. M. Karetnikowa, Istorija petersburskoj..., pp. 90-91.

${ }^{29}$ S. Sawinskij, Istorija ewangel'skich christian-baptistow Ukrainy, Rossiii, Belorussii, czast' II (1917-1967), Sankt Peterburg 2001, pp. 17-18. 
Compared to the pre-revolutionary era, in the 1920s both confessions by a conservative estimate increased their numbers by several dozen per cent. In total in the All-Russian Union of Evangelical Christians there were 3,028 churches, each having some 100 members, and there also could have been as many as 1,000 independent churches in outlying parts of the country that had no connection with larger religious communities. This would mean that at the time around 400,000 Baptists were living in Russia, and since this figure probably represents only baptised believers, their numbers would as much as double if we were also to include their families. ${ }^{30}$ Evangelical Christians also saw their numbers go up, although not as substantially as Baptists', and accounted for one third of the latter.

A rapid rise in the popularity of these confessions in the first post-revolutionary decade came to some degree as a result of the dwindling support of the Orthodox Church. The Communists who had just seized power cracked down on the dominant religion, employing propaganda to discourage people from the Orthodox Church. Those who were persuaded not necessarily turned to atheism, but often joined Evangelical churches.

In the post-revolutionary period unifying trends gained new momentum. In the early 1920s, the leaders of Evangelical Christians and Baptists embarked on a series of initiatives to unite both confessions under a single religious union, but were every time unsuccessful in the face of various disagreements - a military service dispute in particular - although one must note that doctrinal matters were never a dividing issue for these two confessions.

Around 1927, this relatively fortunate period of time for the Baptists and Evangelical Christians was coming to an end. Within the next year the Soviet Union introduced legislation imposing restrictions on religious life and brought actions to eliminate religious life from the state entirely. From now on it was Communism that was supposed to reign as a state religion, not unlike the Orthodox Church in the pre-revolutionary era. ${ }^{31}$

Soon, Evangelical Christians and Baptists were plunged into the worst time in their history, with persecution affecting about 25,000 people between 1929 and 1941. At the beginning, the regime launched a smear campaign, accusing the leadership of Baptists and Evangelical Christians of interfering with Russian affairs, allegedly inspired by western powers. It was not long before the regime started putting on trial prominent figures of these religious communities and sending them to prison, and whilst until the mid-1930s

${ }^{30}$ Ibidem, p. 85.

${ }^{31}$ See M. Kula, Religiopodobny komunizm, Nomos, Kraków 2003; R. Imos, Wiara człowieka radzieckiego, Nomos, Kraków 2006. 
the sentences were relatively lenient, ranging from three to five years, they were becoming increasingly harsh going into the second half of the decade. Although it was a period of intense fear for the entire Russian society, Evangelical Christians and Baptists had every reason to feel particularly exposed, being branded as enemies of the state. The regime cracked down on their churches, eliminating presbyters, preachers, and their most prominent members, and when there was no one who could or would be brave enough to lead, they suspended their activities or continued in secrecy. But it must be also noted that whatever religious disputes there were at the time, they were put to rest entirely, and in the face of such adversity Evangelicals coming from various backgrounds rallied behind he common cause.

Persecution ceased following the aggression of Nazi Germany on the Soviet Union as Joseph Stalin was very much aware that it was time for the entire society to join in with the war effort.

But even before the war ended, the regime inspired a complete turnaround in the fortunes of Evangelical Christians and Baptists. Taking advantage of the renewed unifying sentiments, the regime brought together both religious communities during a congress in Moscow held between 26 and 29 October $1944 .{ }^{32}$ It was not the last unifying moment for Evangelical confessions in the Soviet Union: Evangelical Christian-Baptists were forced to merge with Evangelical Christians from the Pentecostal denomination in 1945, then with the Free Christians in 1946, Christians in the Spirit of Apostles in 1947, and finally, with the Mennonite Brethren in 1963. All these Churches together formed the Union of Evangelical Christians-Baptists (UECB), a singular ecclesiastical organisation headed by the All-Union Council of Evangelical Christians-Baptists (AUCECB), a fairly centralised leadership chaired by President Jakov Zhidkov and Secretary Alexander Karev.

Bringing together such diverse denominations under a single leadership was always going to be not an easy task. The integrity of the newly founded organisation was especially challenged by the speaking in tongues practiced by the Pentecostals. Nevertheless, the regime persisted in its unifying efforts, hoping to hold sway over several confessions at once. Without question the ultimate goal of the regime was to eliminate also the denominations in question, but for the time being it sought to take control of their destiny.

Once Nikita Khrushchev came into power and initiated the Thaw, life improved for those living in the Soviet Union, and also the Evangelical Christians-Baptists started looking into the future with more hope. It

${ }^{32}$ Istorija ewangel'skich christian-baptistow w SSSR, Vsesajuznyj Sovet Evangel'skich Christian-Baptistov, Moskwa 1989, p. 231. 
turned out, however, that whatever the shake-up in the upper echelons of the Communist Party might have been, the purpose of eradicating religion from public life stayed just the same, even if the means chosen to achieve this end turned out to be different. In 1959 the leadership of the UECB was forced to adopt two documents: Regulations on the Union of Evangelical Christians-Baptists, and the Instructional Letter to Senior Presbyters of the AUCECB. ${ }^{33}$ If the churches were to follow closely these new directives, their religious life would amount to little more than religious services, and these would be much more modest than previously. Although in the 1920s the USSR banned religious teachings for people younger than 18 years of age, ${ }^{34}$ under the new regulations no one could be baptised before turning 30 years old, and priests were supposed to encourage the faithful to embrace Soviet culture, despite its often anti-religious rhetoric. To be sure, the faithful were more than used to having restrictions imposed on their religious activity, but historically these restrictions were introduced by whatever secular power there was, while in the new circumstances they were being proposed by no one else but their spiritual leaders.

The Regulations and Instructional Letter were highly unpopular with the faithful. In the wake of this discontent, there emerged a group determined to address this issue by calling for a general congress. Fearing a backlash from the regime, Zhidkov and Karev denied these demands. In response, the group led by Gennadi Kryuchkhov set up an Initiative Group which won a substantial numbers of supporters. Unable to come to an agreement with the leadership of the UECB, in 1965 the Initiative Group established a new ecclesiastical organisation - the Council of Churches of the Evangelical Christian Baptists. ${ }^{35}$

It is difficult to judge the events of the late 1950s and early 1960s. ${ }^{36}$ While it is true that the leadership of the UECB was rather pliant to Communist demands, the Initiative Group on its part was disobedient to their own leaders, largely ignoring the political climate in the USSR. In any case, however, this internal struggle eventually played into the hands of the regime as the UECB was now purged of various radical activists who, as members

${ }^{33}$ See M. Newolin, Raskol ewangel'sko-baptistskogo dwiżenija w SSSR (1959-1963), Szandal, Sankt Petersburg 2005, pp. 80-89.

${ }^{34}$ S. Sawinskij, Istorija..., pp. 44-45.

${ }^{35}$ T. Nikol'skaja, Istorija dwiżenija baptistow iniciatiwnikow, "Almanach po Istorii Russkogo Baptizma” 3/2004, pp. 63-87.

${ }^{36}$ G. Gartfeld, K sporu meżdu WSCh-B i S.C. Ech-B, “Almanach po Istorii Russkogo Baptizma” 3/2004, pp. 346-348. 
of unregistered and thus illegal Churches, could be later persecuted in an open and legitimate way. ${ }^{37}$

In the post-Thaw period, Evangelical Christians-Baptists were given more opportunities to practice their religion, being allowed, for example, to establish some relations with their fellow believers in the West, although their intensity came nowhere near as lively as the exchanges in the 1920s, and meant that from time to time some believers were allowed to attend an international conference or receive foreign delegates in Moscow. But some organisations in the West sought to support Christians in the USSR, for example Slaviska Missionen from Sweden, Licht im Osten from Germany, or the Slavic Gospel Association from the United States, who were arranging for Bibles, literature, and journals to be smuggled to Russia. ${ }^{38}$ Important work was also done by Christian stations such as Trans World Radio and Voice of Andes, who were broadcasting in Russian and other languages spoken in the USSR. Substantial aid from the West was flowing to churches established by the Initiative Group, which properly presented their persecutions to the public in the West. ${ }^{39}$

By the 1970s, and more so in the 1980s, the Communist ideology was in a slow decline. Communism, however, still enjoyed the status of an official religion, and therefore other competing churches could only be tolerated at best. This also included the groups that formed the UECB, but at the turn of the 1960s and the 1970s there occurred a major generational shift in the organisation: many older activists who had lived through Stalinist times passed away and their younger colleagues took over the reins of the organisation. As its Secretary General, the AUCECB appointed in 1971 Alexander Bitchkov, who went on to hold this appointment for the next twenty years. There were major changes under the new leadership, and the Churches belonging to the UECB could now enjoy a period of relative stability. However, unlike in the 1920s, this "Baptist sect," with some 500,000 believers, was not allowed to engage with the largest society. Sometimes the regime did make certain concessions, as in 1982 when it signed off on the visit of Billy Graham, ${ }^{40}$ but it appeared to be an exception to the general rule. It was not until the

${ }^{37}$ See G. Vins, Wierni do końca, transl. A. Walicka, Dabar, b.m. i r.w.

${ }^{38}$ Also Polish believers were involved in these initiatives: K. Muranty, Lotnik ewangelista, Warszawa 2000, pp. 155-162.

${ }^{39}$ W. Sawatsky, Soviet Evangelicals Since World War II, Herald Press, Kitchener 1981, pp. 389-390.

40 B. Graham, Just As I Am. The Autobiography of Billy Graham, Harper One, New York 2011, p. 540. 
late 1980s, following the rise into power of the liberal Mikhail Gorbatchev, that life would finally improve for these religious groups.

This brief history of the Evangelical Christian-Baptists recounted above, allows us to reflect on the origins of the particular elements making up this religious phenomenon. It would be naturally a gross oversimplification to say that the origins of the Evangelical Christian-Baptists can be traced back to partially Russian and partially foreign influences. The idea of something being "Russian" is already not entirely clear, as one may be referring to a single ethnic group or an ethnically diverse empire, whereas something "foreign" may often be found anywhere in the world.

It is undoubtedly an important question whether the nature of the Evangelical Christian-Baptists is indigenously Russian. ${ }^{41}$ The first thing that comes to mind when we think of religion in Russia is usually the Orthodox Church, maybe the Old Believers, while Protestantism tends to be associated with the culture of the West. These essentially stereotypical opinions are not entirely wrong, and perhaps statistically correct. But one cannot help but note that instead of remaining an obscure foreign sect, the Evangelical Christians-Baptists rose relatively quickly as a powerful religious movement deeply embedded in the society and culture of Russia. It is true, however, that the indigenous character of this movement is itself a fairly complicated issue, not least because of the other than Russian origins of ideas that the Evangelical Christians-Baptists stand for.

Let us first discuss the German origins of the Russian Baptists. As already noted, their emergence was to some degree brought about by the German colonists, mostly those of the Mennonite persuasion, who came to southern Russia and Ukraine in the second half of the $18^{\text {th }}$ century. This is not to say that Russian Baptists from the $19^{\text {th }}$ century are directly related to a group founded in the $16^{\text {th }}$ century by Menno Simons. Mennonites who had their share in bringing about Baptism in Russia had been already living there for two or three generations as part of the German population in the ethnically diverse empire of the Romanovs. Furthermore, Baptist ideas were being spread by the Mennonite Brethren, a breakaway Mennonite group that was not known in Germany, where the Mennonite movement began.

It must also be noted that Russians or Ukrainians were not converting to the Mennonite or Lutheran faith practiced by Germans settling in Russia in the $18^{\text {th }}$ century, who on their part were reluctant to embrace the Baptist

${ }^{41}$ S. Sawinskij, Wozniknowenie baptizma w Rossii, www.rusbaptist.stunda.org/savinski.html [access: 15.10.2015], pp. 20-21. 
teachings. Therefore, it appears that the Slavic population of the empire was not particularly drawn to the "German faith."

Before Russians or Ukrainians took to establishing Baptist churches, Molokans saw the emergence of Water Molokans and Evangelical Christians led by Zakharov, whereas Stundists were becoming increasingly popular among Russians or Ukrainians previously belonging to the Orthodox Church. Russia has longstanding sectarian traditions; nevertheless, these groups were also close to Protestantism, and the Stundists were directly inspired by Protestant ideas, with which Baptists felt a sense of affinity.

As already noted, there were four breeding grounds for Baptists and Evangelical Christians: southern Russia and Ukraine, Taurida Governorate, Transcaucasia, and Saint Petersburg. In each of them, however, the process of embracing the core principles of the Baptist faith proceeded differently, and nowhere were they adopted immediately. For example, the Ukrainian Stundists originally insisted on atonement and religious rebirth, only later arriving at the belief that baptism should be received exclusively by adult believers. A similar path was followed by those who were awakened by the preaching of Lord Redstock in Saint Petersburg, while the Transcaucasian Molokans were practicing baptism before they came to the conclusion that it should be preceded by atonement and justification by faith.

The various terminologies adopted by the followers of these religious groups offer some insight into our discussion. Those coming from the Mennonite community preferred to be called the Mennonite Brethren, while Germans with no Mennonite background were simply directly adopting the Baptist faith. Molokans originally described themselves as Christians baptised on the basis of faith, and it was not until later on that they started referring to themselves as Baptists following the example of the German Baptists. Meanwhile, the awakened residents of the capital were simply thinking about themselves as Petersburg believers before they eventually settled for the name Evangelical Christians. It appears, therefore, that the term "Baptists" did not emerge at once, but was rather inspired by like-minded Christians from foreign lands who described themselves as Baptists. Those, however, who were converted through the efforts of the aristocratic milieu in Saint Petersburg eventually stayed with the name Evangelical Christians.

Finally, Evangelical-Baptist communities did persevere in Russia, which perhaps may be the ultimate evidence for their indigenous Russian character. In less than half a century these initially small and dispersed religious groups substantially grew in numbers and started engaging with one another in an effort to unite the movement and gradually build ecclesiastical structures. 
They were gaining ground not because of religious freedom, but rather in spite of persecution organised by the Orthodox Church and the secular regime. One may argue that if these groups had not been firmly embedded in the social and cultural environment of Russia, but rather incited through the efforts of foreign preachers, they would have not won over the hundreds of thousands of believers joining the continuously growing communities despite the unceasing persecution. It is also important to note that these believers were able to survive once they emigrated. ${ }^{42}$

Naturally, we should also reflect on how much these preachers contributed to the emergence of the Evangelical Christians and Baptists. It would certainly be a difficult task to measure it precisely. In Russia, there were no Baptist missions run by foreign churches, and while it is true that German settlers were receiving preachers from Germany, these visits were usually arranged by the hosts themselves. Also, the famous Lord Redstock came to the capital of the Russian empire on the invitation of Ms Chertkova as a guest, and never really achieved any other standing, although it must be said that he used his visitant role skilfully to pursue his evangelical mission.

But Baptism was spreading in Russia also in other ways than through the teachings of individual foreigners preaching the Gospel while travelling the land. In the second half of the $19^{\text {th }}$ century, Baptism was becoming a vibrant movement growing in various parts of the world, and Russia was also swept up by this surge. Russian Baptists - calling themselves variously at the time - were simply involved in the movement as they were graduating from western theological universities or buying western literature and translating it into Russian and other languages spoken in the empire. It goes without saying that it was the East that mostly benefitted from these exchanges with the West, as it was almost exclusively in Anglo-Saxon countries where Baptism originally emerged and later grew from the early $17^{\text {th }}$ century to the $19^{\text {th }}$ century. And when in the $19^{\text {th }}$ century Baptist churches began emerging all over the world, they would seek support from their fellow believers in America, England, and other Protestant countries. Russia could not compete with these countries in terms of the national wealth and religious freedom that created an environment for those religious groups to run theological universities or publish religious literature.

It must be said, however, that the global Baptist movement had great contributors in various Russians, who were answering to the uniquely Rus-

${ }^{42}$ G. Charłow, Russko-Ukrainskomy Sojuzu 90!, “Sejatel’ Istiny” 5-6/2009, p. 5; G. Bołnew, Czego trebujet ot tebja gospod,' “Sejatel' Istiny” 5-6/2009, pp. 18-23; K. Prochorow, Podwig wery. Unikal'nye swidetel'stwa o żizni christian w SSSR, Omsk 2010. 
sian calling by the name of bogoiskatiel'stwo, or, in short, a burning desire to get to the bottom of humanity's most vital questions. For centuries, this force pushed people down various ways ${ }^{43}$ and, as it happened, in the $19^{\text {th }}$ and the $20^{\text {th }}$ century some found Baptism and Evangelical Christianity to be the answer to those inquiries. This desire was fuelled by religious inquisitiveness, spiritual fervour, and a readiness for martyrdom. Needless to say, precisely these passions inspired the Russian Baptists and Evangelical Christians.

Religious inquisitiveness, or, in other words, a lively interest in religion, transcends the entire Russian society and peasants, bourgeois, and aristocracy. This omnipresent interest could have had various causes, one of which could be the intellectual poverty of the Orthodox theology in Russia, the other having religious matters left in the secular hands of philosophers and writers. ${ }^{44}$ In any case, many Russians were disillusioned with the official Orthodox Church, and were joining various sects, finding greater appeal in their beliefs and practices, exhibiting sometimes some trademark Protestant qualities ${ }^{45}$ such as individualism or simplicity. The Water Molokans, who had no foreign inspirations, seem to be closest to the Protestant beliefs, and were partially responsible for bringing about Baptism in Russia. And, once it came into being, Baptism undeniably sparked a genuine interest in Russian society. A powerful movement, increasingly popular domestically and globally, it could not be easily dismissed as just another sect.

Russian religiosity was often enveloped in mysticism, with this inclination displayed in particular by some sects. The predecessors of Baptism, however, tended to be more rational in approaching religious life, which could be attributed to their study of the Bible and settling doctrinal matters upon consulting the Scripture, which required a certain intellectual rigour. It is true that over time this intellectual rigour may eventually damp the religious spirit, something which happened to the Mennonites in the first half of the $19^{\text {th }}$ century, who then sought to revive their religious communities with Pietist beliefs that suggested a more emotional approach to faith, rather than conceiving it as a purely intellectual exercise. Eventually, it must have

${ }^{43}$ M. Karetnikowa, Russkoe bogoiskatel'stwo. Nacional'nye korni ewangel'sko-baptistskogo dwiżenija, “Almanach po istorii russkogo baptizma” 2006, pp. 3-84.

${ }^{44}$ M. Bierdiajew, Rosyjska idea, tłum. J.C. - S.W., Fronda, Warszawa 1999, pp. 171172.

${ }^{45}$ Protestant ideas were also sometimes taken up by the Orthodox Church in the Balkans: see N. Zernow, Wschodnie chrześcijaństwo, transl. J.S. Łoś, Pax, Warszawa 1967, pp. 111-113. 
been because of the influence of these Mennonite teachings that Baptist communities did absorb some of the Pietist spirit. ${ }^{46}$

For the secular power and the Orthodox Church, too much freedom for religious expression was not a welcomed circumstance, the less so when it was encouraging the rise of social groups reluctant to bow to the supreme authority of the powers that be. Openly severing ties with the Orthodox faith, Baptists and Evangelical Christians refused to recognize the authority of the Orthodox Church, which cracked down on the Baptists in an attempt to force the believers back to the Orthodox faith. This, however, was never to come to pass as the Russian Baptists and Evangelical Christians would rather suffer than relinquish their faith.

Things were similar during the seven decades of the Communist rule. Although, in a sense, Communism replaced the Orthodox Church, there was no way in the Soviet Union that the Evangelical Christians-Baptists could challenge the established order. Their only hope could be that the expectations that came with declared tolerance would not turn out to be a broken promise, as it had happened many times before.

The Evangelical Christians-Baptists emerged into a vibrant religious culture, even if these religious groups were inspired by ideas that were not necessarily genuinely Russian. These ideas, however, could not thrive in a largely hostile environment, which is especially true when we come to think of the Communist rule in Russia.

But the Soviet Union is no more, much like its leadership, and things in Russia, as well as in other countries that emerged from the collapse of the Soviet Union, have largely changed for the better. Religious life has been no exception, and this has included also the Evangelical Christians-Baptists, for whom the fall of the Soviet Union meant a complete shake-up of their organisational structures, with separate religious organisations established for the post-Soviet republics. Pentecostals left the Union to create their own ecclesiastical structures, and the Mennonite community saw its numbers falling in the wake of emigration.

The Evangelical Christians-Baptists were now enjoying a period of unprecedented freedom and were quick to reach out to their fellow believers from abroad, most notably the American Baptists. It did not take long before Baptists in Russia, but also in Ukraine and Belarus, adopted various practices and beliefs from their American brothers. This comes as no surprise as in this new world the Baptists needed guidance they did not have under

${ }^{46}$ M. Karetnikowa, Russkoe bogoiskatel'stvo..., pp. 87-89. 
the Communist rule. For example, being now able to offer education, the Baptists have opened in Russia a number of universities, following in this regard the American example. For these people of faith, however, the most important thing is to be able to fully participate in the life of the Evangelical community around the world. 
